\title{
ISOLATION AND PRELIMINARY CHARACTERIZATION OF A $O$-NITROBENZALDEHYDE-DEGRADING Alcaligenes SP. ND1
}

\author{
Yu Fang-Bo ${ }^{1 *}$; Guan Li-Bo ${ }^{1}$; Zhou Shan ${ }^{1 *}$ \\ ${ }^{1}$ Departament of Environmental Sciences, School of Environmental Technology, Zhejiang Forestry University, \\ Zhejiang Province, China, 311300
}

Submitted: November 10, 2007; Returned to authors for corrections: April 08, 2008; Approved: November 02, 2008.

\begin{abstract}
This paper reports the isolation and characterization of a new $o$-nitrobenzaldehyde (ONBA)-degrading bacterium, Alcaligenes sp. ND1. ND1 degraded almost all ONBA $\left(100 \mathrm{mg} \mathrm{L}^{-1}\right)$ in M9 medium within 36 hours. The key enzyme(s) involved in the initial biodegradation was a constitutively intracellular enzyme(s). This bacterium has great potential utility for bioremediation.
\end{abstract}

Key words: Alcaligenes sp.; Biodegradation; o-nitrobenzaldehyde.

A large variety of chemicals are commercially produced and newly synthesized each year. Some compounds and byproducts are discharged into the environment during use and manufacture of these chemicals. Their widely use has caused great damages to the environment and to living organisms (2). In China, as an important intermediate for the synthesis of pharmaceuticals, such as nifedipine (Adalat, Procardia), dyes, agrochemicals and other organic compounds, industrial demand of ONBA is great (19). Meanwhile, severely pollution hazard is created because of its toxic and recalcitrant nature. It is toxic either by ingestion, by contact, or by inhalation at low concentrations (https://fscimage.fishersci.com/msds/ 91095.htm). It is, therefore, necessary to treat ONBA-containing wastewaters before their discharge into the environment, although no specific acceptable limit of ONBA has been decided in treated wastewater.

Microbial metabolism is the main mechanism responsible for degradation of ONBA in the environment, and there is a need to develop remediation with efficient ONBA-degrading microorganisms to eliminate or minimize the contamination. However, before this study only one Pseudomonas sp. strain, ONBA-17, which could utilize ONBA as sole carbon and nitrogen source, has been reported (19). Although, this strain could completely degrade $100 \mathrm{mg} \mathrm{L}^{-1} \mathrm{ONBA}$ in $48 \mathrm{~h}$ and tolerate up to a higher concentrations $\left(400 \mathrm{mg} \mathrm{L}^{-1}\right)$, and showed potential to be a good candidate for bioremediation, isolation of novel strains is still necessary due to the consideration of new bacterial resources for biodegrading ONBA.

In this work, we have isolated an ONBA-degrading bacterium from activated sludge. The isolate, strain ND1, was Alcaligenes sp., which has not been reported previously to own the ability to degrade ONBA. The characteristics of ONBA degradation by the isolate and the distribution of ONBA-degrading enzymes from strain ND1 were preliminarily studied.

Activated sludge samples were sampled from a municipal wastewater treatment plant in the city of Hangzhou, Zhejiang Province, China. The enrichment mixture was incubated at $25^{\circ} \mathrm{C}$ and shaken at $150 \mathrm{rpm}$ on a rotary shaker (19). Six subcultures were performed before isolation was done. The final enrichment culture was plated on MSM agar plate containing $15 \mathrm{~g}_{\text {agar L }} \mathrm{L}^{-1}$. After incubation for 3 days at $28^{\circ} \mathrm{C}$, single colonies were restreaked on the fresh MSM agar plates. The isolates were used to inoculate MSM to test their degradation activity. One isolate, designated as ND1, from among those with the best ONBA metabolism was selected for further identification and characterization. The concentration of ONBA was determined with a gas chromatography method as described by Yu et al. (19).

The identification was performed according to Bergey's Manual of Determinative Bacteriology (9). The 16S rRNA genes of bacteria were amplified with the universal primers $8 \mathrm{~F}$ and

*Corresponding Author. Mailing address: Zhejiang Forestry University, Environmental Engineering, Department of Environmental Engineering, Linan, ZJ, 311300. Tel.: +86-571-63741350 Fax: +86-571-63741350. E-mail: superboywonder@sina.com 
reverse primer 1492R (18). Multiple alignments of the sequences were performed using the CLUSTAL W program version 1.8 (17). Phylogenetic and molecular evolutionary analyses were conducted using MEGA version 3.0 (10). Tree was constructed by using the neighbor-joining method and dataset was bootstrapped 1000 times (13).

The optimum temperature and $\mathrm{pH}$ for ONBA removal was determined according to the method described by Dai et al. (6), but with ONBA as degradation substrate. Determination of MICs for 13 metal ions was performed using the methods described by Yu et al. (19).

Cells from the early stationary phase of growth were centrifuged, washed, and suspended in M9 minimal salts medium (16) without ammonium chloride. After the value of $\mathrm{OD}_{600 \mathrm{~nm}}$ had been adjusted to $1.0,5 \%$ inoculum was inoculated into M9 medium with $100 \mathrm{mg} \mathrm{L}^{-1} \mathrm{ONBA}$ as sole carbon or nitrogen source. Fructose, $100 \mathrm{mg} \mathrm{L}^{-1}$, was supplemented when ONBA was used as sole nitrogen source. Samples were collected from the cultures at 6-hour intervals. The degradation effect was evaluated according to the GC method.

The localization of degrading enzymes was conducted by the method of osmotic shock (8). The solutions were each transferred $(10 \%, \mathrm{v} / \mathrm{v})$ into phosphate buffer solution $(\mathrm{pH} 7.0)$ containing $100 \mathrm{mg} \mathrm{ONBA} \mathrm{L}^{-1}$ and incubated at $30^{\circ} \mathrm{C}$ with shaking at $120 \mathrm{rpm}$. The reaction mixtures at zero time and $10 \mathrm{~h}$ were examined against a blank control containing the same reaction mixture, except that ONBA was omitted.

To determine whether the enzyme system responsible for ONBA biodegradation was inducible or constitutive, two batches of cells were grown in M9 medium containing $1 \%$ fructose in the presence and absence of $100 \mathrm{mg} \mathrm{L}^{-1}$ of ONBA. Total protein was estimated by the method of Lowry et al. (11), using bovine serum albumin as the standard.

The reaction mixture $(1.0 \mathrm{~mL})$ contained $50 \mathrm{mmol}$ of phosphate buffer (pH 7.4), $13.24 \mathrm{mmol}$ of ONBA, and cell crude extract. Reactions were performed at $30^{\circ} \mathrm{C}$ for 12.5 min without shaking, and the residual ONBA was quantified by the GC method. Enzyme activities were expressed as units (micromoles of ONBA decreased per minute) per milligram of protein.

Bacterial colonies could be observed on the isolation and purification medium using ONBA as the sole carbon and energy sources after 3-5 days incubation. All the colonies were identical morphologically, circular, low-convex, about $2 \mathrm{~mm}$ in diameter, smooth, shining and entire, from which strain ND1 was isolated. It was a Gram-negative, short-rod or coccobacillary bacterium, $1.2-2.5 \mu \mathrm{m}$ long and $0.7-1.0 \mu \mathrm{m}$ in diameter, with peritrichous flagella. The optimum temperature and $\mathrm{pH}$ for the strain growth were $30^{\circ} \mathrm{C}$ and 7.6 , respectively.

A $1.5 \mathrm{~kb} 16 \mathrm{~S}$ rDNA fragment was amplified from the total DNA of the isolate and sequenced. Its GenBank accession number is EU072720. It showed high sequence similarity to Alcaligenes species (especially to A.faecalis) (Fig. 1). According to its morphology, cultural appearance, and physiologic and biochemical characteristics mentioned above, together with the phylogenetic analysis, the strain ND1 was preliminary identified as Alcaligenes sp. Until now, no described ONBA-degrading bacterium has been related to Alcaligenes.

The ability to utilize ONBA as the sole source of carbon seems to be shared by relatively few microorganisms. ONBA is so recalcitrant that large numbers of bacteria cannot use it as a substrate for growth. To date, only Yu et al. (19) reported a pure culture of Psudomonas species, strain ONBA-17, with the ONBAdegrading capability. Alcaligenes species are widespread in nature and can be obtained from various sources, such as water, soil, and living organisms. Some strains of this genus are known to be involved in the biodegradation of quite a few pollutants, such as benzoate and chlorobenzoates, polychlorinated biphenyls, pyridine, phenol, and so on $(1,3,4,7,14)$. This was the first report that Alcaligenes has ONBA-degrading ability. Most Alcaligenes strains have been isolated from wastewater treatment plants or bioremediation sites of contaminated soils because of their degradative capabilities, which suggests that further study of this genus may help to understand the ecological diversity of these organisms and their usefulness as biodegradation bacteria.

The optimum temperature and $\mathrm{pH}$ ranges for ONBA removal by strain ND1 were $28-35^{\circ} \mathrm{C}$ and $6.9-8.1$ (data not shown), respectively. However, the most optimum temperature and $\mathrm{pH}$ for ONBA degradation should be $30^{\circ} \mathrm{C}$ and $\mathrm{pH}$ 7.6.

The organism can use ONBA as sole carbon and nitrogen sources. The strain grew and degraded better when ONBA was used as sole nitrogen source. ONBA, $100 \mathrm{mg} \mathrm{L}^{-1}$, could be degraded almost completely within 36 hours by the strain. However, more than 54 hours were needed when ONBA was used as sole carbon source or as both sole carbon and nitrogen sources. The addition of fructose indeed accelerated the degradation, which to some extent implied that the degradation may be a cometabolic process.

Owing to the fact that the most abundant pollutants in wastewater are heavy metals (15), the ability of microbial strains to grow in the presence of heavy metals is necessary and helpful. As presented in Table 1, strain ND1 is strongly multiresistant. Although its resistance to $\mathrm{Cu}^{+}, \mathrm{Cu}^{2+}, \mathrm{Pb}^{2+}, \mathrm{Mn}^{2+}$, and $\mathrm{Ni}^{2+}$ is not as good as ONBA-17, it owns higher $\mathrm{MICs}$ of $\mathrm{AgNO}_{3}, \mathrm{FeSO}_{4}$, and $\mathrm{FeCl}_{3}$. Together with previously data, the isolate could be considered as a good candidate for biotreatment of industrial wastewaters containing ONBA.

With GC analysis, we found that no objective substance could be detected in the reaction mixture containing ONBA and the intracellular fraction solution taken at $10 \mathrm{~h}$ (data not shown). Besides, there was no downtrend of ONBA content in the mixture containing the extracellular and membrane fraction solution (data not shown). These results show that the enzyme(s) involved in the initial degradation of ONBA in ND1 was intracellular enzyme(s). 


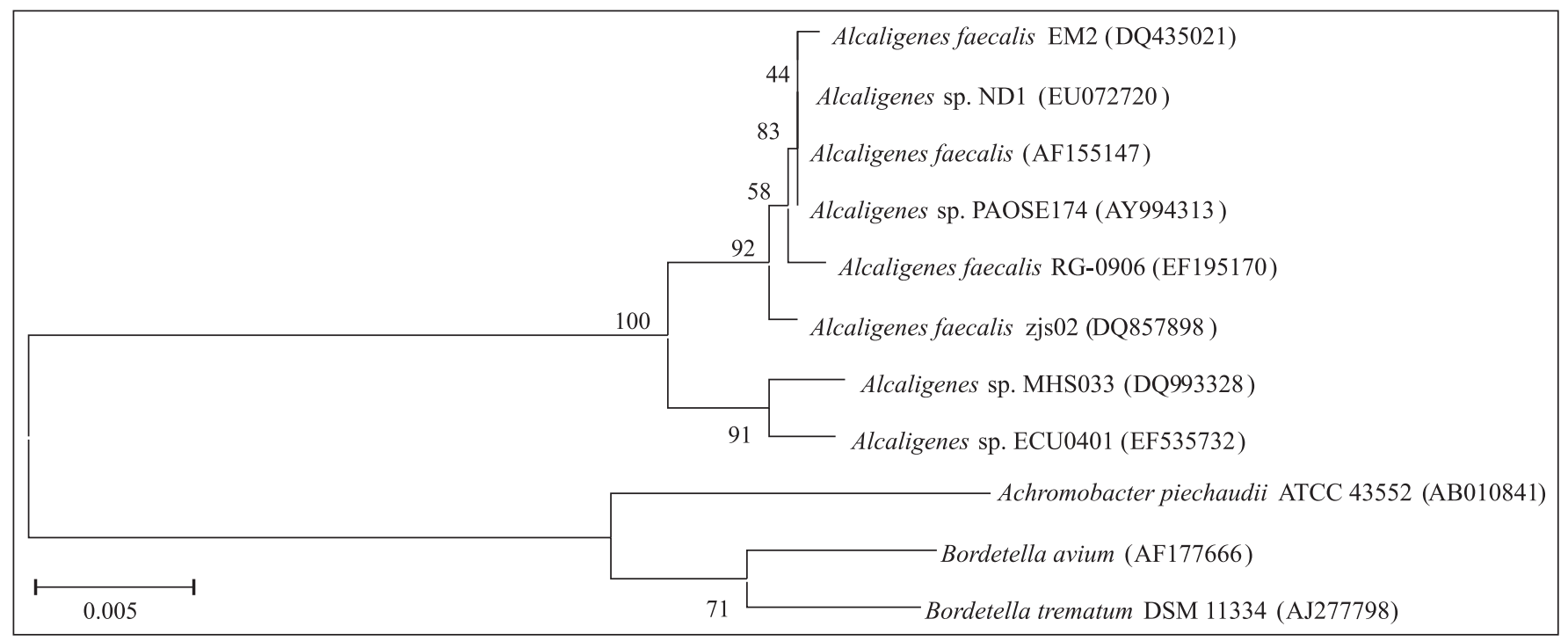

Figure 1. Phylogenetic analysis of the isolate ND1 and related species by Neighbor Joining method. Bootstrap values (\%) are indicated at the nodes. The scale bars represent 0.005 substitution/site. The accession numbers are in parentheses.

Table 1. Minimal inhibitory concentrations $(\mu \mathrm{M})$ of strain Alcaligenes sp. ND1 and Pseudomonas sp. ONBA-17 to 13 heavy metals.

\begin{tabular}{cccccc}
\hline Metal ion & ND1 & ONBA-17 & Metal ion & ND1 & ONBA-17 \\
\hline $\mathrm{Li}^{+}$ & 3,600 & 3,200 & $\mathrm{Zn}^{2+}$ & 6,000 & 6,000 \\
$\mathrm{Ag}^{+}$ & 3,200 & 2,400 & $\mathrm{Mn}^{2+}$ & 4,800 & 6,400 \\
$\mathrm{Cu}^{+}$ & 6,000 & 8,000 & $\mathrm{Ni}^{2+}$ & 1,600 & 3,200 \\
$\mathrm{Cu}^{2+}$ & 6,000 & 8,000 & $\mathrm{Fe}^{2+}$ & 7,200 & 6,000 \\
$\mathrm{Hg}^{2+}$ & 1,800 & 1,200 & $\mathrm{Fe}^{3+}$ & 7,200 & 6,000 \\
$\mathrm{Ba}^{2+}$ & 1,280 & 1,280 & $\mathrm{Co}^{4+}$ & 1,600 & 1,600 \\
$\mathrm{~Pb}^{2+}$ & 4,800 & 6,000 & & & \\
\hline
\end{tabular}

Cells induced by ONBA and noninduced cells showed ONBA biodegradation activities of $18.13 \pm 3.09$ and $17.69 \pm 4.97$ $\mathrm{U}$ (mg protein $)^{-1}$, respectively, indicating that there was no significant discrepancy in ONBA degradation between induced and noninduced cells. This finding also indicated that there may be a constitutive enzyme(s) in the cells responsible for ONBA biodegradation.

In the previously researches, there are two pathways for $o$ nitrobenzoate (ONB) degradation (at different substrate concentrations levels) in a Gram-positive Arthrobacter protophormiae strain, $\mathrm{RKJ} 100(5,12)$. ONB is reductively degraded to $o$-hydroxylaminobenzate (2-HABA) which is a substrate for two different enzymes, a reductase and a mutase, that convert HABA to anthranilate (AA) and 3-hydroxyanthranilate (HAA), respectively; these further serve as substrates for ring cleavage enzymes (12). In this work we confirmed the existence of ohydroxylaminobenzaldehyde (OHABA) (data not shown), and proposed that ONBA degradation pathway of strain ND1 is likely to same with that of strain RKJ100. However, it still needs further research to gain solid proofs.

In summary, we describe a novel ONBA-degrading bacterium isolated from activated sludge in a municipal wastewater treatment plant using a culture enrichment technique. The Alcaligenes species strain ND1 enriches our knowledge on Alcaligenes species that can grow on aromatic compounds. Strain ND1 has a high tolerance to ONBA toxicity and is multiresistant to heavy metals. It owns good potential for biotreatment of ONBA-containing industrial wastewaters or in situ bioremediation of ONBA-contaminated soils.

\section{RESUMO}

\section{Isolamento e caracterização preliminar de lcaligenes SP ND1 degradador de o-nitrobenzaldeido}

Esse trabalho relata o isolamento e a caracterização de uma nova bactéria degradadora de $o$-nitrobenzaldeido (ONBA), Alcaligenes sp ND1. A bactéria ND1 decompôs todo o ONBA (100mg. $\mathrm{L}^{-1}$ ) do meio M9 em 36 horas. A enzima-chave envolvida na biodegradação inicial foi uma enzima constitutiva intracelular. Esta bactéria apresenta um potencial de aplicação para bioremediação.

Palavras-chave: Alcaligenes sp, biodegradação, $o$ nitrobenzaldeido. 


\section{REFERENCES}

1. Ampe, F.; Uribelarrea, J.L.; Aragao, G.M.F. (1997). Lindley N D. Benzoate degradation via the ortho pathway in Alcaligenes eutrophus is perturbed by succinate. Appl. Environ. Microbiol., 63: 2765-2770.

2. Annachhatre, A.P.; Gheewala, S.H. (1996). Biodegradation of chlorinated phenolic compounds. Biotechnol. Adv., 14: 35-56.

3. Baek, S.H.; Yi, C.; Le, S.T. (2001). Aerobic nitrate respiration by a newly isolated phenol-degrading bacterium, Alcaligenes strain P5. Biotechnol. Lett., 23: 627-630.

4. Bott, T.L.; Kaplan, L.A. (2002). Autecological properties of 3chlorobenzoate-degrading bacteria and their population dynamics when introduced into sediments. Microbial. Ecol., 43: 199-216.

5. Chauhan, A.; Jain, R.K. (2000). Degradation of $o$-nitrobenzoate via anthranilic acid (o-aminobenozate) by Arthrobacter protophormiae RKJ100: a plasmid-encoded new pathway. Biochem. Biophys. Res. Commun., 267: 236-244.

6. Dai, X.Z.; Jiang, J.D.; Gu, L.F.; Li, R.; Li, S.P. (2007). Isolation and characterization of an atrazine-degrading bacterium strain SA1. Wei Sheng Wu Xue Bao, 47: 544-547.

7. Fava, F.; Di, G.D.; Marchetti, L.; Quattroni, G.; Marraffa, V. (1993). Aerobic mineralization of chlorobenzoates by a natural polychlorinated biphenyl-degrading mixed bacterial culture. Appl. Microbiol. Biotechnol., 40: 541-548.

8. Harold, C.N.; Leon, A.H. (1965). The release of enzymes from Escherichia coli by osmotic shock and during the formation of spheroplasts. J. Biol. Chem., 240: 3685-3692.

9. Holt, J.G.; Krieg, N.R.; Sneath, P.H.A.; Staley, J.T.; Williams, S.T. (eds). (1994). Genus Alcaligenes, In: Bergey's manual of determinative bacteriology, 9th ed. Baltimore: Williams \& Wilkins, p. 361-373.
10. Kumar, S.; Tamura, K.; Nei, M. (2004). MEGA3: Integrated software for Molecular Evolutionary Genetics Analysis and sequence alignment Brief Bioinformat, 5: 150-163.

11. Lowry, O.H.; Rosebrough, N.J.; Farr, A.L.; Randall, R.J. (1951) Protein measurement with Folin-phenol reagent. J. Biol. Chem., 193: 265-275.

12. Pandey, G.; Paul, D.; Jain, R.K. (2003). Branching of $o$-nitrobenzoate degradation pathway in Arthrobacter protophormiae RKJ100: identification of new intermediates. FEMS. Microbiol. Lett., 229 231-236.

13. Pereira, R.M.; Silveira, E.L.; Scaquitto, D.C.; Pedrinho, E.A.N.; Val Moraes, S.P.; Wickert, E.; Alves, L.M.C.; Macedo Lemos, E.G.M. (2006). Molecular characterization of bacterial populations of different soils. Braz. J. Microbiol., 37: 439-447.

14. Ronen, Z.; Bollag, J.M. (1992). Rapid anaerobic mineralization of pyridine in a subsurface sediment inoculated with a pyridine-degrading Alcaligenes sp. Appl. Microbiol. Biotechnol., 37: 264-269.

15. Sabhi, Y. (1990). Toxicology of heavy metals on aquatic organisms: Environmental and experimental aspects. Rabat, Morocco. (Ph. D. Dissertation. University of Mohammed V.)

16. Sambrook J.; Fritsch E.F.; Maniatis, T. (eds). (1989). Molecular cloning: A laboratory manual, 2nd edn, Vol. 1-3, Cold Spring Harbor, New York, Cold Spring Harbor Laboratory.

17. Thompson, J.S.; Higgins, D.G.; Gibson, T.J. (1994). CLUSTAL W: improving the sensitivity of progressive multiple sequence weighing, position-specific gap penalties and weight matrix choice. Nucl. Acids. Res., 22: 4673-4680.

18. Wilson, K.H.; Blitchington, R.B.; Greene, R.C. (1990). Amplification of bacterial $16 \mathrm{~S}$ ribosomal DNA with polymerase chain reaction. $J$. Clin. Microbiol., 28: 1942-1946.

19. Yu, F.B.; Shen, B.; Li, S.P. (2006). Isolation and characterization of Pseudomonas sp. strain ONBA-17 degrading $o$-nitrobenzaldehyde. Curr. Microbiol., 53: 457-461. 